\title{
AUTO 2.0: \\ photonics inside
}

\author{
Jacques COCHARD \\ Clémentine BOUYÉ \\ TEMATYS, Exploration of \\ Photonics Markets \\ jcochard@tematys.com \\ cbouye@tematys.com
}

Photonics manufacturers are always on the lookout for new application fields beyond the more established markets in defence, science and telecommunications, in order to sustain the growth of their sector. About 15 years ago, the introduction of powerful lasers for welding, marking or cutting glass and metal gave photonics a toehold in the motor industry, but its use since then has mainly been confined to the outside of the vehicle, with the notable exception of headlight optics.

way as possible. Radar and sonar technologies already allow us to analyse the immediate environment, but mapping wider areas requires new technologies.

So what are the latest products and how widely are they being used?

\section{A rapidly growing world market fol cars}

While the statistics for France's automotive industry generally make for gloomy reading, the global market continues to enjoy sustained growth. Production plunged to around 64 million light vehicles per annum in the wake of the economic and financial crisis of 2008 , but by 2013 it had bounced back to more than 83 million vehicles, and most industry observers expect it to top the 100 million mark around 2019.

This growth is mainly being driven by rising purchasing power in emerging nations. Above a GDP (at purchasing power parity) of $\$ 10,000$ per capita, car ownership goes up significantly, stabilizing at around 500-600 per 1000 people (rate achieved in most OECD countries). Countries like China, Malaysia and Turkey are currently hovering around this threshold, reflected in a massive increase in new consumers.

These new consumers have a very different perception of cars from the one that prevails in Europe, and \begin{abstract}
ronment and communicate this information to the driver in as natural a portunities for in-vehicle photonics. As we will see below, photonic devices will mainly be used to acquire a highly accurate picture of the vehicle's enviand extremely reliable car parts. These tumbling costs and the emergence of
\end{abstract}

\section{You Spoke We Listened!} New \& Improved Website

- Additional Laser Grade Options

- Improved Product Specifications www.cvilaseroptics.com

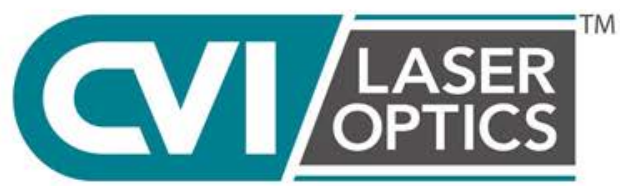

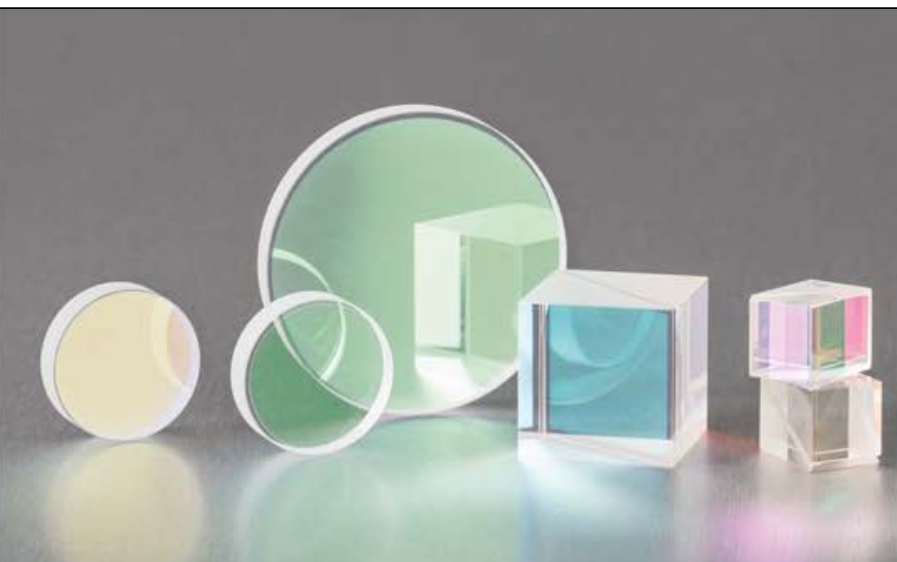

$20 \%$ OFF your online order Use promocode: PHOTONQ Offer expires 4/30/17. One coupon per customer 


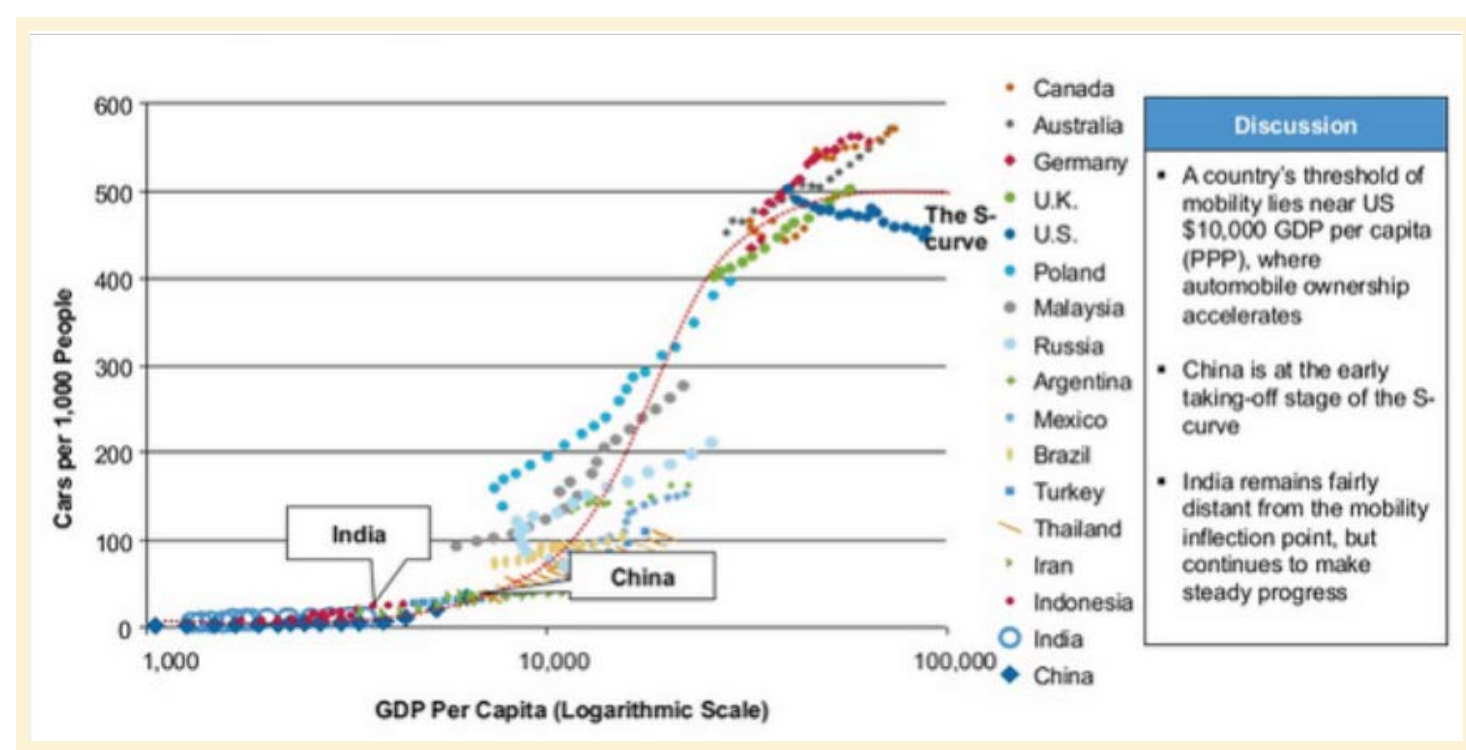

Figure 1. Number of registered motor vehicles per country (source: China Automotive Industry Yearbook, 2014). automatically assume that they will be connected (e.g. vehicleto-vehicle, vehicle-to-infrastructure, vehicle-to-home). This, of course, is good news for two areas of the photonics industry in particular (information display and 3D mapping).

\section{Vehicles assembled closer to their markets}

Although this growth in consumption is having an impact on motor production and assembly, with a major shift to East and Southeast Asian countries (from $8 \%$ of production in 2000 to $36 \%$ in 2014; see Fig. 2), it has not so far dented European production, which has remained stable at around 20 million vehicles per annum for the past 15 years.

Within the European Union, Germany is currently home to $20 \%$ of all assembly plants (41 out of 208 ) and $30 \%$ of Europe's production of motor vehicles. In 2014, France produced 1.8 million vehicles at 33 plants. These figures give us a good idea of the size of the different markets that are accessible to photonics:

- parts and systems for light vehicles: 80-100 million vehicles; parts and systems for luxury cars: $10 \%$ of world production (i.e. 8-10 million vehicles), mainly manufactured by Mercedes, Audi and BMW;

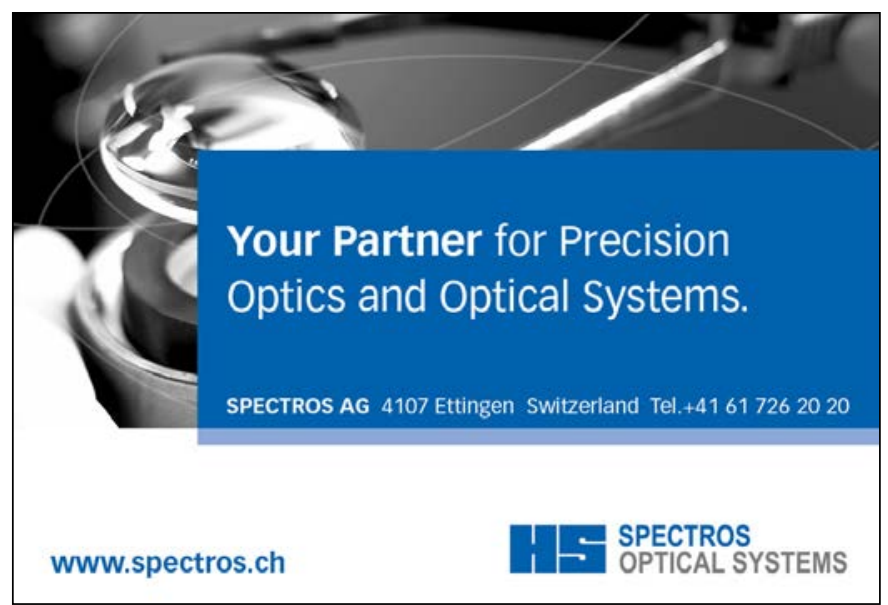

- systems for production lines: approximately 1000 assembly plants (20\% in the 28 countries of the European Union); - testing systems (headlamp beam testers, crash tests): 100 or so testing and R\&D facilities.

\section{Strong growth in photonic products and technologies}

The market for in-vehicle photonic components (i.e. first five categories listed in Table 1) was estimated to be worth \$16.7 billion in 2013 , and is expected to rise to $\$ 26.7$ billion by 2018, corresponding to a mean annual growth of $9.8 \%$ over the next 5 years. This growth is unevenly distributed across the different segments, being mainly focused on advanced driver assistance systems (ADASs) - technologies that will ultimately give rise to automated vehicle (AV) solutions. The ADAS market is expected to grow by $21.4 \%$ - growth that should be set against the far more modest growth of the automotive market (3.2\%) and megasuppliers (3.0\%) over the same period (source: Roland Berger management consultants, 2013).

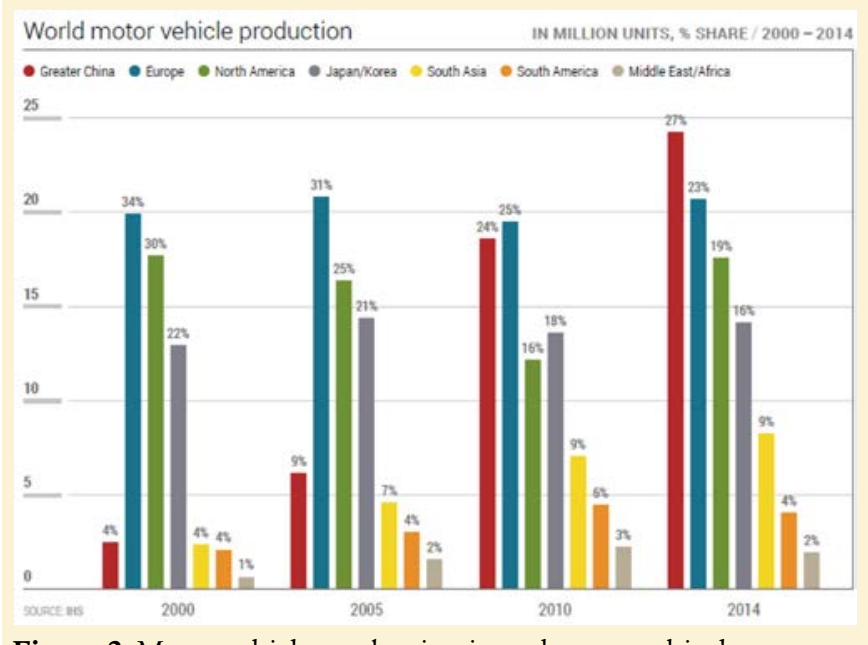

Figure 2. Motor vehicle production in each geographical zone (source: Information Handling Services (IHS), 2014). 


\begin{tabular}{|c|c|c|c|c|c|c|c|}
\hline Where? & \multicolumn{5}{|c|}{ In the Car } & \multicolumn{2}{|c|}{ Car Manufacturing } \\
\hline $\begin{array}{c}\text { Types } \\
\text { of Systems }\end{array}$ & $\begin{array}{l}\text { Sensing and } \\
\text { imaging } \\
\text { systems }\end{array}$ & $\begin{array}{c}\text { Communication } \\
\text { systems }\end{array}$ & $\begin{array}{l}\text { Screens, } \\
\text { Displays, } \\
\text { Projectors }\end{array}$ & $\begin{array}{c}\text { Systems } \\
\text { based on LED, } \\
\text { OLED and } \\
\text { other sources }\end{array}$ & $\begin{array}{l}\text { Photovoltaic } \\
\text { systems }\end{array}$ & $\begin{array}{c}\text { Laser } \\
\text { systems }\end{array}$ & $\begin{array}{l}\text { Sensing and } \\
\text { imaging systems }\end{array}$ \\
\hline $\begin{array}{l}\text { Photonic } \\
\text { Functions }\end{array}$ & $\begin{array}{l}\text { Acquiring } \\
\text { information }\end{array}$ & $\begin{array}{l}\text { Transmitting } \\
\text { information }\end{array}$ & $\begin{array}{l}\text { Delivering } \\
\text { information }\end{array}$ & $\begin{array}{c}\text { Light } \\
\text { providing }\end{array}$ & $\begin{array}{c}\text { Energy } \\
\text { providing }\end{array}$ & Processing & $\begin{array}{l}\text { Acquiring } \\
\text { information }\end{array}$ \\
\hline $\begin{array}{l}\text { Products } \\
\text { examples }\end{array}$ & $\begin{array}{l}\text { - Imaging: } \\
\text { CMOS } \\
\text { cameras, IR } \\
\text { cameras ... } \\
\text { - Sensing: } \\
\text { Various types } \\
\text { of sensors (see } \\
\text { figure below) } \\
\text { - Proximity } \\
\text { and gesture } \\
\text { control }\end{array}$ & $\begin{array}{l}\text { Optical } \\
\text { communication } \\
\text { systems in cars: } \\
\text { - MOST } \\
\text { networks, } \\
\text { - FlexRay ... }\end{array}$ & $\begin{array}{l}\text { Displays for: } \\
\text { - Entertain- } \\
\text { ment, } \\
\text { - Driver } \\
\text { information, } \\
\text { - GPS } \\
\text { information, } \\
\text { - Others ... }\end{array}$ & $\begin{array}{l}\text { Lighting } \\
\text { systems } \\
\text { (inside \& } \\
\text { outside the } \\
\text { car) based on: } \\
\text { - LED, } \\
\text { - OLED, } \\
\text { - Lasers ... }\end{array}$ & $\begin{array}{l}\text { Photovoltaic } \\
\text { devices for } \\
\text { energy } \\
\text { providing in } \\
\text { cars. }\end{array}$ & $\begin{array}{l}\text { Laser systems } \\
\text { for: } \\
\text { - Welding, } \\
\text { - Cutting, } \\
\text { - Drilling, } \\
\text { - Marking ... }\end{array}$ & $\begin{array}{l}\text { Non Destructive } \\
\text { Testing \& QA/ } \\
\text { QC: } \\
\text { - Machine vision, } \\
\text { - Reflectometry, } \\
\text { - Thermography } \\
\text { - Profilometry } \\
\text { - Shearography } \\
\text {..- }\end{array}$ \\
\hline
\end{tabular}

Table 1. Photonics components according to function (source: Tematys, 2015).

\section{Lighting: a market undergoing a major overhaul}

Optics made early inroads into the automotive industry via lighting, where the light from halogen, xenon and now light-emitting diode (LED) headlamps needed to be distributed as efficiently as possible. This continues to be the most important segment (more than $62 \%$ of value in 2018), and is undergoing increasingly rapid technological advances, as shown in Figure 3.

The simultaneous advent of new, energy-efficient light-source technologies (LEDs and possibly lasers), display technologies, digital image processing, and greater in-vehicle integration is giving rise to very high value-added advanced frontlighting systems (AFS) that reduce glare to oncoming vehicles and may, in the medium term, be used to signal to pedestrians.

\section{In-vehicle equipment dominated by Asia}

Following in the wake of network telecommunications developments, the early 2000s saw growth in both in-vehicle communication systems (transceivers and plastic optical fibre (POF) transmission) and low-cost components (photodiodes, LEDs for automotive interior lighting) for noncritical systems. Production of these components mainly took place in Asia (Taiwan, Japan, South Korea, then China).

\section{Fisheye lenses for ADAS}

In the motor industry, the term fisheye refers to the ultra-wide-angle lenses used in ADAS. If they are to deliver reliable identification in variable and complex environmental conditions, they must have uniform contrast across the field of view and for the whole of the visible spectrum. Their high level of intrinsic distortion must also be calibrated, in order to guide the identification algorithms.

It is vital to optically characterize these lenses so that the best ones can be selected

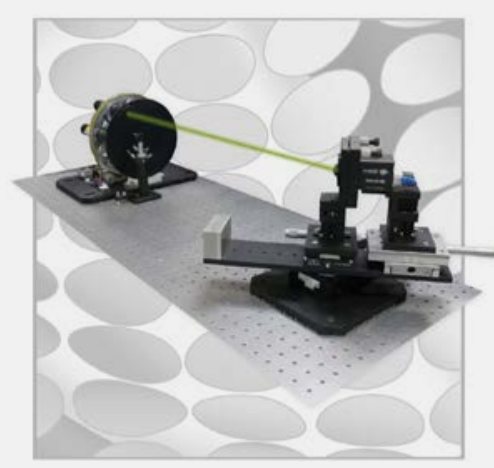

Test bench developed by Phasics and the suppliers' compliance with specifications can be checked. To gauge the actual impact of a lens on image quality, it is not enough to measure the optical transfer function (OTF). Wavefront measurement does, however, meet the needs of manufacturers, as it gives direct access to all the components of the light transmitted through the lens. In partnership with Renault, Phasics has developed a rigorous, automated polychromatic test bench that supplies the OTF, aberration and distortion values for the optical system's exit pupil in a single acquisition for each field of view.

\section{Optical Spectrum Analyzer OSA20

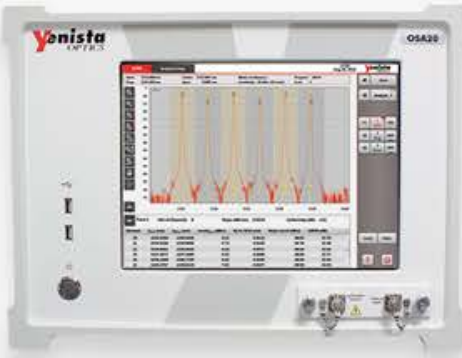

Fast \& Accurate

Spectral Range

1250-1700 nm

\section{Sweep Speed $2000 \mathrm{~nm} / \mathrm{s}$}

Resolution Bandwidth $20 \mathrm{pm}$

Wavelength Accuracy \pm 10 pm / 1500-1640 nm $\pm 25 \mathrm{pm} / 1250-1700 \mathrm{~nm}$

\section{Easy-to-Use}

- Multi-touch screen

- Application-oriented analysis modes

- Full suite of analysis tools

Visit our website for a detailed overview www.yenista.com/osa20

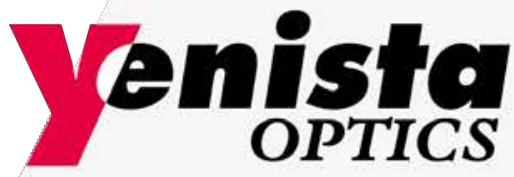

Tel.: +33 (0)296483716 sales-emea@yenista.com www.yenista.com 


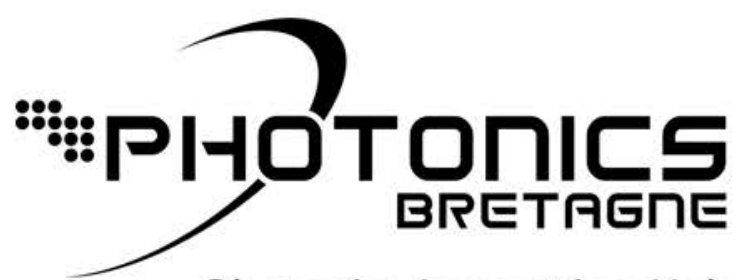

Photonics Innovation Hub

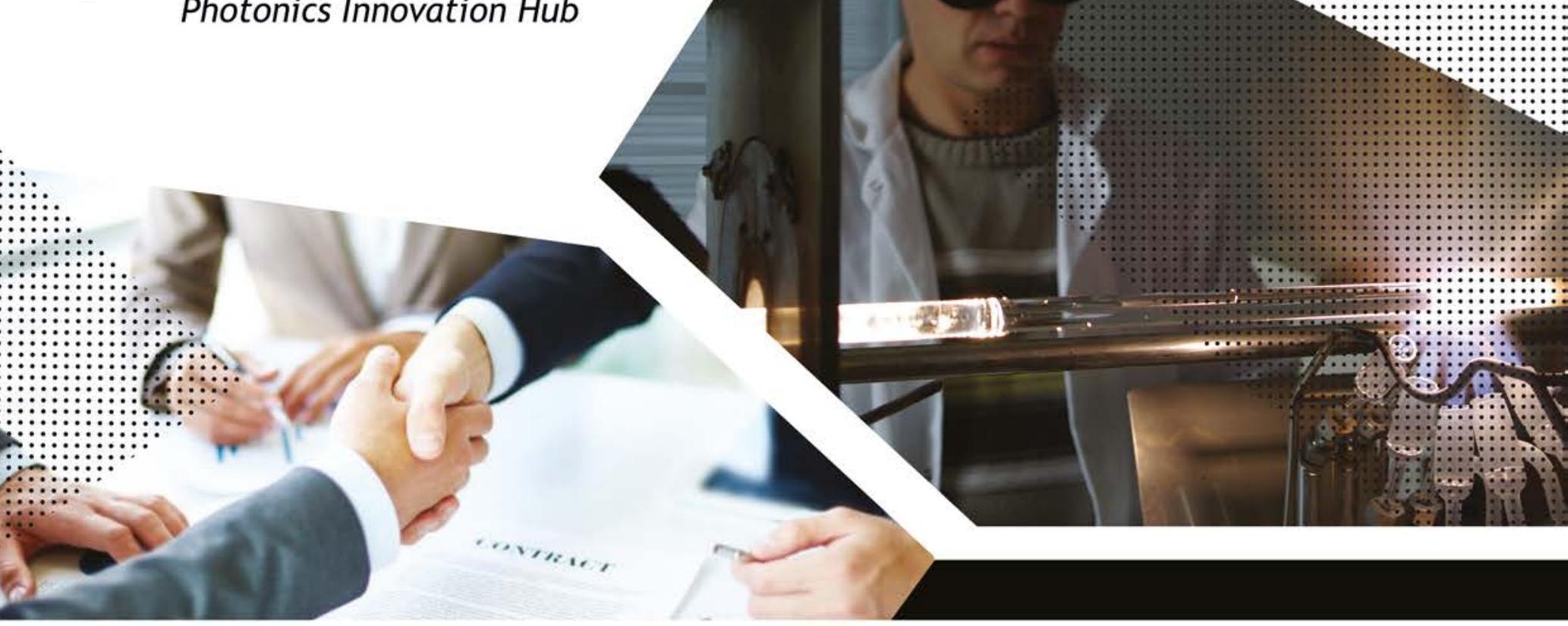

\section{When an innovative cluster meets a RTO}

\section{A dual expertise within a Photonics Innovation Hub}

\section{A cluster}

supporting innovation, working for the development of photonics and its applications in Britanny.
(12) Market studies
(Q) Marketing strategy
(\$o) Project engineering
Technological consulting

LASER 26. - 29. JUNI 2017 | MESSE MUNCHEN

\section{A Research and Technology Organisation}

expert in the production of specialty optical fibres (PCF, LMA, multicore...) and components (capillaries, tapers...).

\section{Brand name : PERF)}

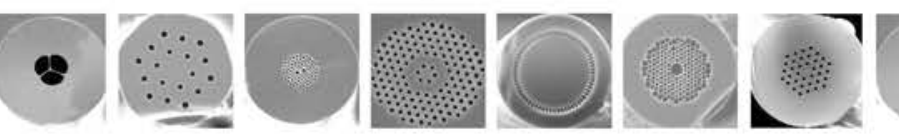

\section{Characterisation, modeling \& simulation}

\section{Join us on our booth B3.129}

Technical studies

Biophotonics engineering

to:
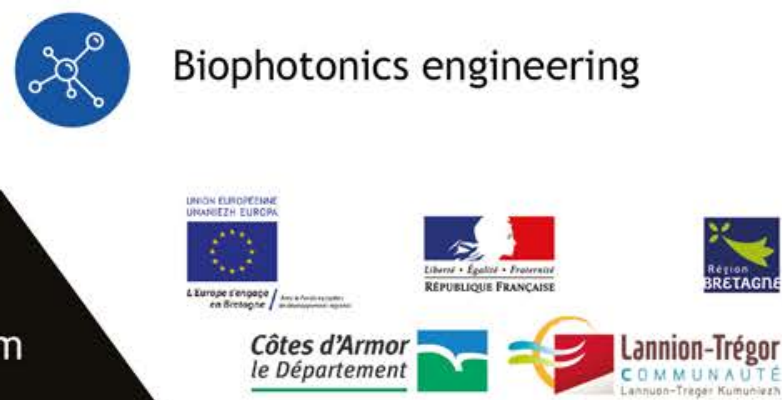

Let's talk about your needs

+33 (0)2964858 89 | contact@photonics-bretagne.com www.photonics-bretagne.com 


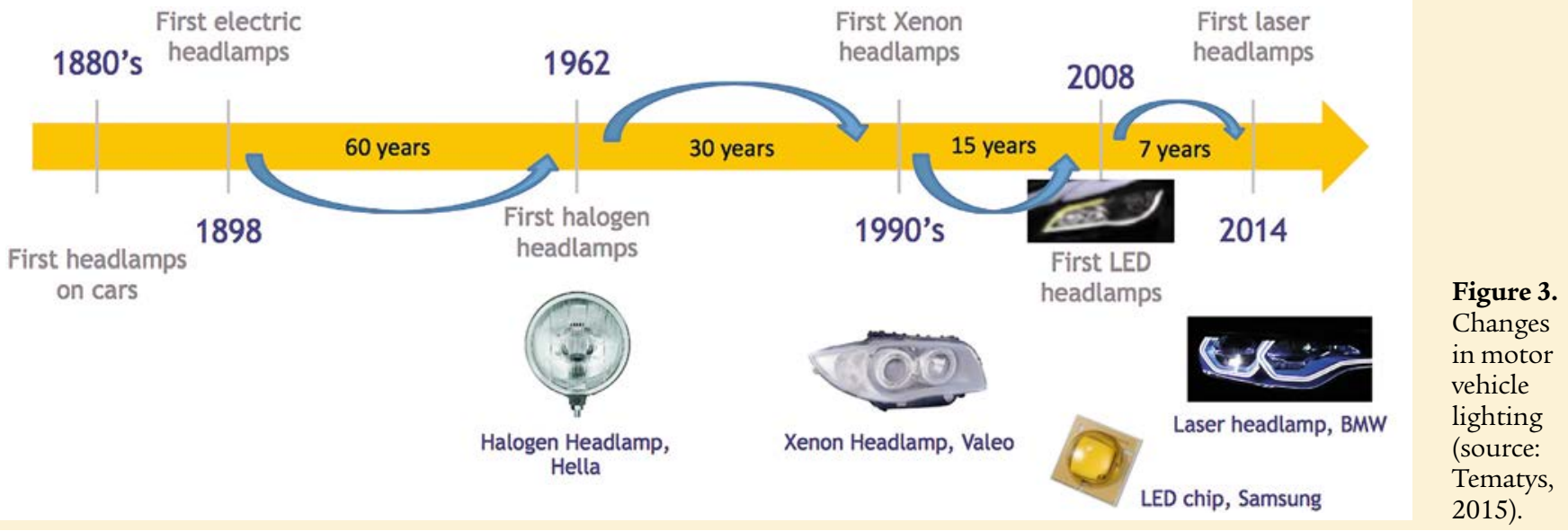

\section{Assisted driving: considerable potential for growth}

Today, however, the greatest potential for growth lies in driver assistance, which is set to undergo massive expansion within the near future. In 2014-2015, six of the largest parts manufacturers (Bosch, Magna, Continental, Denso, Hyundai, ZF) embarked on major development and integration programmes. Bosch, the world leader, reported a doubling of sales of cameras and radars between 2013 and 2014, and they almost doubled again over the previous 12 months. As for motor manufacturers, Toyota had equipped the whole of its range with ADAS by the end of 2016, while Renault intends to do the same for many of its models over the next 3 years. As Cap Gemini's 2015 report made clear, many consumer countries are already looking beyond driver assistance to self-driving or driverless cars.

The cameras and radars that are currently on the market clearly have limitations when it comes to, say, authorizing a vehicle to automatically change lanes. By providing $360^{\circ}$ digital images of the environment, light-detection and ranging (LiDAR) sensors will prove crucial for automated driving in environments that are simple to model, such as motorways and bypasses. Valeo and its partner Ibeo, along with Bosch, which already has more than 10 sensors developed in house (cameras, radars, LiDARs), are expanding the footholds established by Velodyne for in-vehicle LIDARs and Vitronic for infrastructure LiDARs. Experts predict that, in 4 years' time, the market for these cameras, novel sensors and innovative display modes will be worth in excess of $€ 8$ billion.

These components still have one or two technical issues affecting their reliability in complex environments (e.g. rain or fog), while costs remain prohibitive (Velodyne's second-generation LiDARs have a hefty price tag of $\$ 30,000)$, but in a few months' time

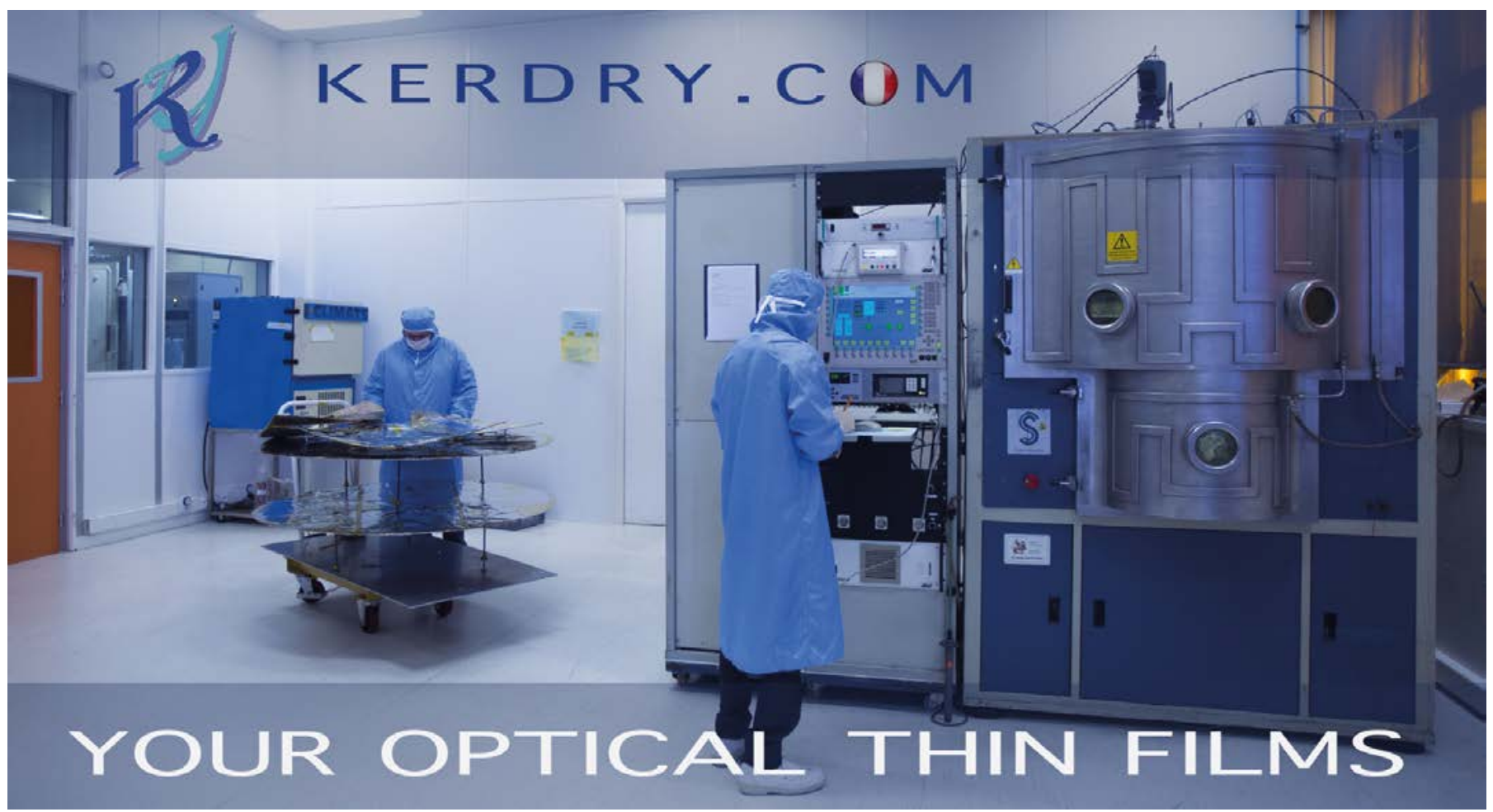




\section{PHASICS}
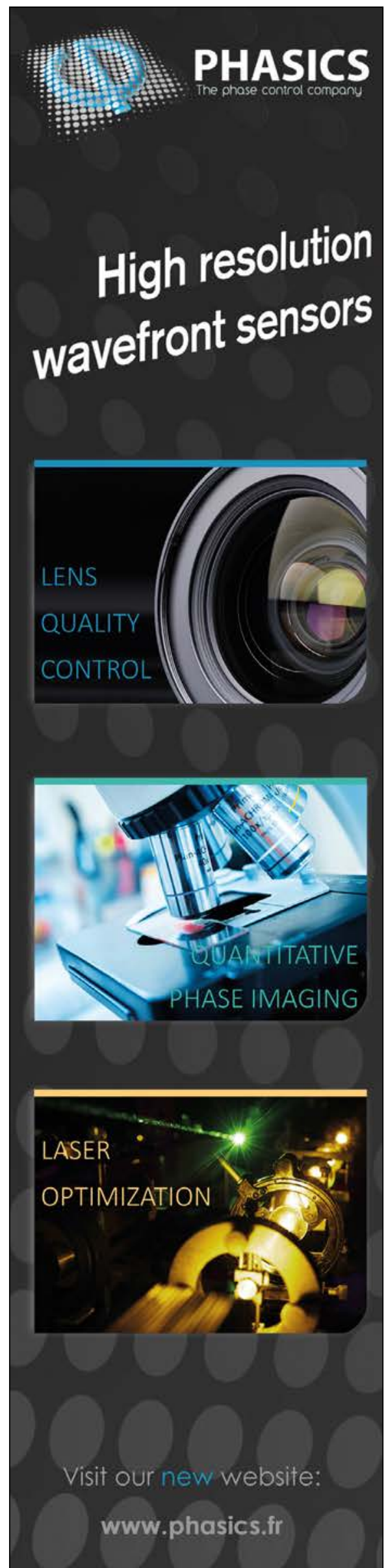

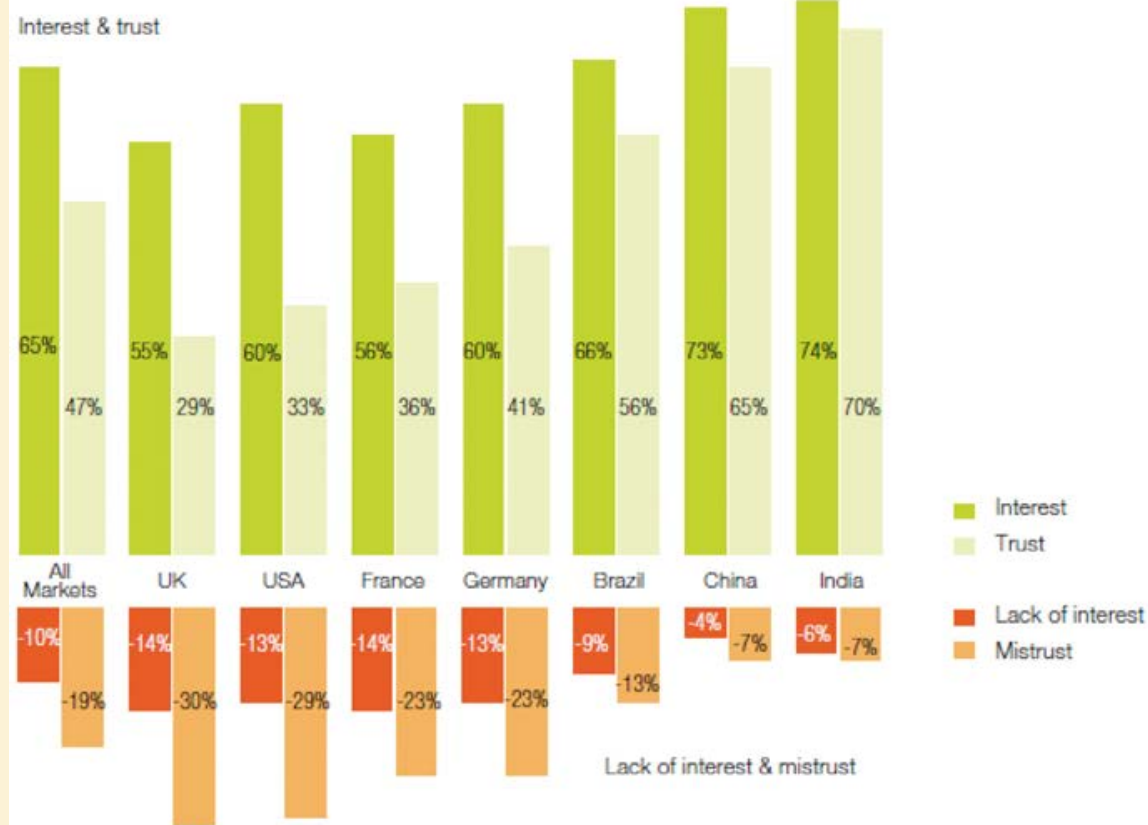

Figure 4. Interest and trust in self-driving cars by country, 2015 (source: Cap Gemini).

we should start to see prices plummet to below $€ 1000$ with no significant loss in performances.

Alongside these components, most future growth is expected to be in data analysis software. With the increasing use of sensors, the data they yield will have to be organized and analysed in real time, be it for safety purposes or for monitoring driver vigilance. This will offer opportunities for new players to come into the motor industry. The Israeli company MobilEye is already working with most of the world's leading parts manufacturers to deliver safety diagnoses, while French firms such as Innov' and Chronocam are positioning themselves in specific market segments (e.g. driver vigilance assistance).

\section{Potential pitfalls facing the photonics industivy}

Photonics offers the only means of generating a 3D map of the environment (via visible-light and infrared cameras, and LiDARs), meaning that today's radar-based and ultrasound sensors will be relegated to secondary roles in the future. The first markets (premium and luxury ranges) for this new technology represent 10-15 million vehicles. If the 70 million vehicles in the lower categories are to be equipped, costs will have to be substantially reduced (which is precisely what the manufacturers of visible CMOS cameras are doing).

Recent changes in the way that polluting emissions are measured, and the

\begin{tabular}{|c|c|c|c|c|c|}
\hline & \multicolumn{5}{|c|}{ INTERIOR } \\
\hline & IMAGING & SENSING & LIGHTING & COMMUNICATION & DISPLAYS \\
\hline COMFORT & $\begin{array}{l}\text { Cameras for rear } \\
\text { passengers } \\
\text { observation }\end{array}$ & $\begin{array}{l}\text { Spectroscopy for } \\
\text { air quality } \\
\text { monitoring } \\
\text { IR active systems } \\
\text { for gesture } \\
\text { recognition }\end{array}$ & $\begin{array}{l}\text { Halogen lamps, } \\
\text { Neon lamps, LEDs, } \\
\text { Optical fibers } \\
\text { OLEDs }\end{array}$ & & $\begin{array}{l}\mathrm{ED} / \mathrm{LCD} \text { for } \\
\text { dashboard }\end{array}$ \\
\hline $\begin{array}{l}\text { ENTER- } \\
\text { TAINMENT }\end{array}$ & & & Diffractive optics* & $\begin{array}{l}\text { MOST (Media } \\
\text { Oriented Systems } \\
\text { Transport) for } \\
\text { communication } \\
\text { between media in } \\
\text { the car } \\
\text { Plastic Optical } \\
\text { Fiber }\end{array}$ & $\begin{array}{l}\text { LCD, electrochromic } \\
\text { displays, ... for } \\
\text { passengers }\end{array}$ \\
\hline
\end{tabular}

Table 2. Photonics components for the vehicle interior (source: Tematys, 2015). 


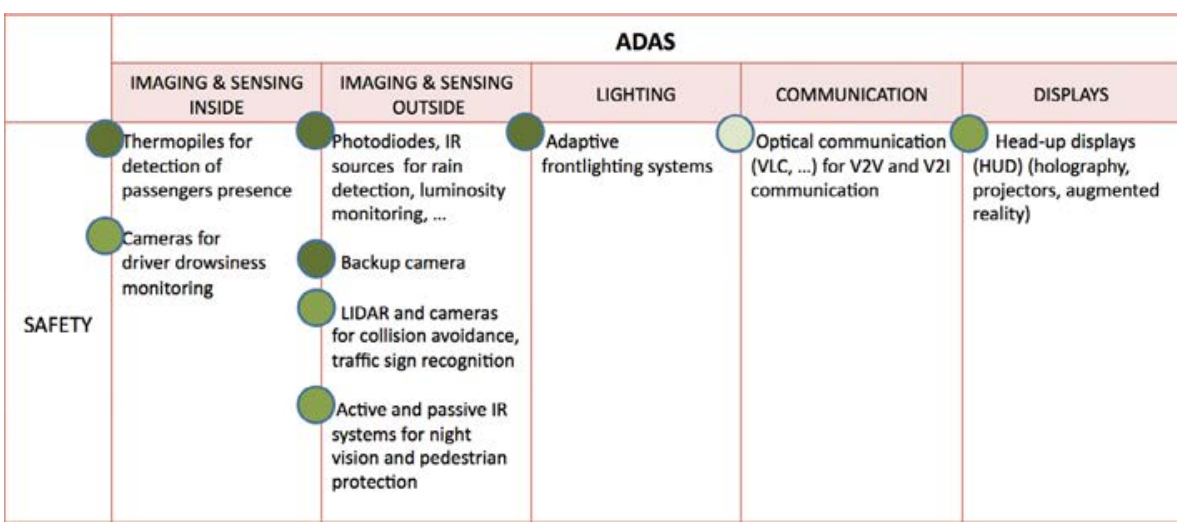

Table 3. Photonics components for ADAS functions.

environmental impact of these emissions in new consumer countries (China, Malaysia), will require the development of devices to measure emissions of pollutant gases and particulates not just on the outside of the vehicle but also, probably, on the inside, too, as the air quality of vehicle interiors is particularly poor. This will open up new markets for a whole range of spectroscopy components.

These fast-growing markets are not just attracting the attention of photonics manufacturers. The problem of vehicle emissions measurement has led to the development of very reasonably priced electrochemical solutions. In the fields of vehicle-to-vehicle and vehicle-to-infrastructure communication, WiFi offers an attractive alternative to $\mathrm{LiFi}$, with established standards and a wide range of available expertise, plus the ability to spread development costs across huge fields of application and, ultimately, support the cost reductions inherent to the motor parts market. As for in-vehicle communication, the winner so far in the competition between Ethernet and media-oriented systems transport (MOST) fibre-optic transceivers has been the standardized Ethernet technology, as the MOST format has failed to make headway in other application markets.

Although these new photonic technologies will benefit from the large automotive markets in the medium term, they still need to find other major applications if leading manufacturers are to come together and set industry-wide standards. It should also be borne in mind that there is no point collecting good-quality information if it cannot be properly analysed and exploited. It is therefore vital for photonics and IT manufacturers to team up to ensure the lasting development of in-vehicle photonics.

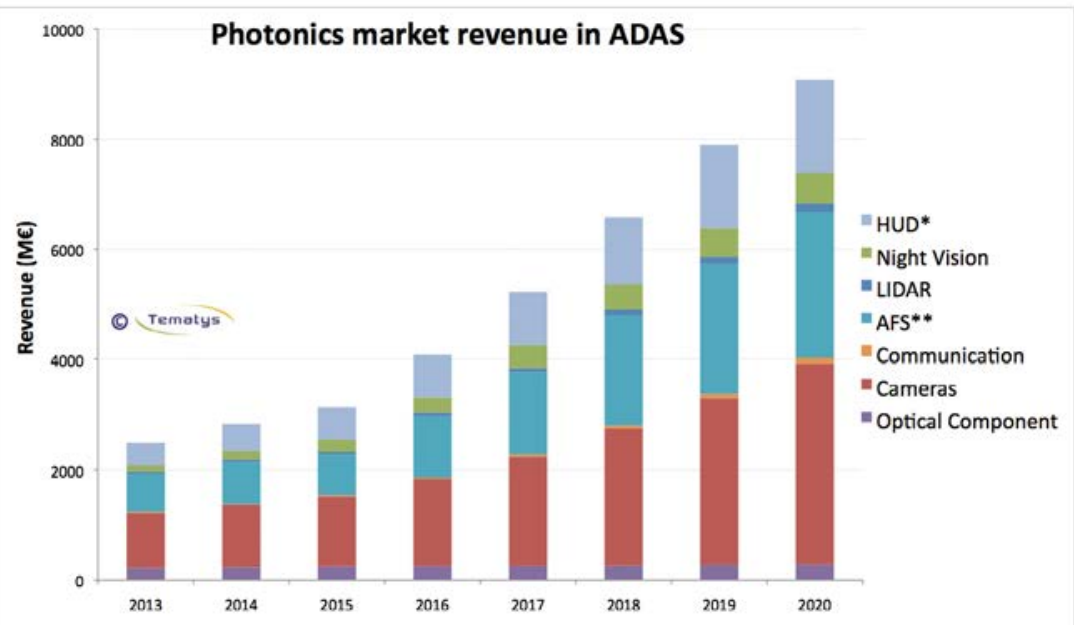

Optical components include basic optical components such as photodiodes or thermopiles - HUD : Head-Up Display “* AFS : Adaptive Frontlighting System

Figure 5. Photonic component market for ADAS functions (source: Tematys, 2015).

\section{Tematys}

\section{EXPLORATION OF PHOTONICS MARKETS}

Tematys is a team of highly qualified experts, committed to provide the most accurate and updated information on markets and applications of photonic technologies.

Our added value relies on an extensive network of > 10000 contacts within photonic companies, research labs and public institutions.

It relies also on the participation to more than 20 conferences and exhibition dealing with Photonics every year.

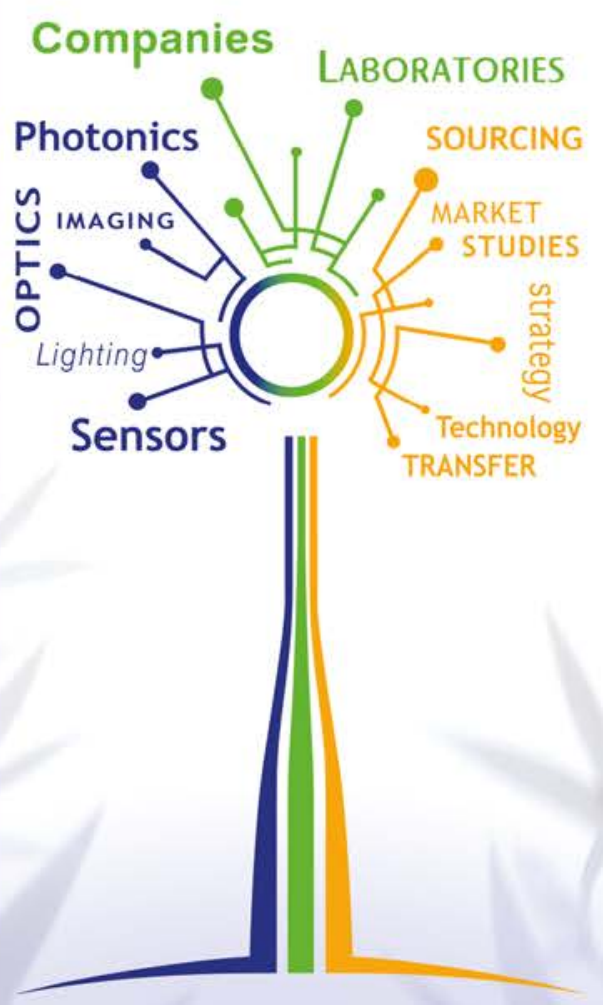

www.tematys.com info@tematys.com

TEMATYS

6 cité de Trévise $\cdot 75009$ Paris

France 
(2)
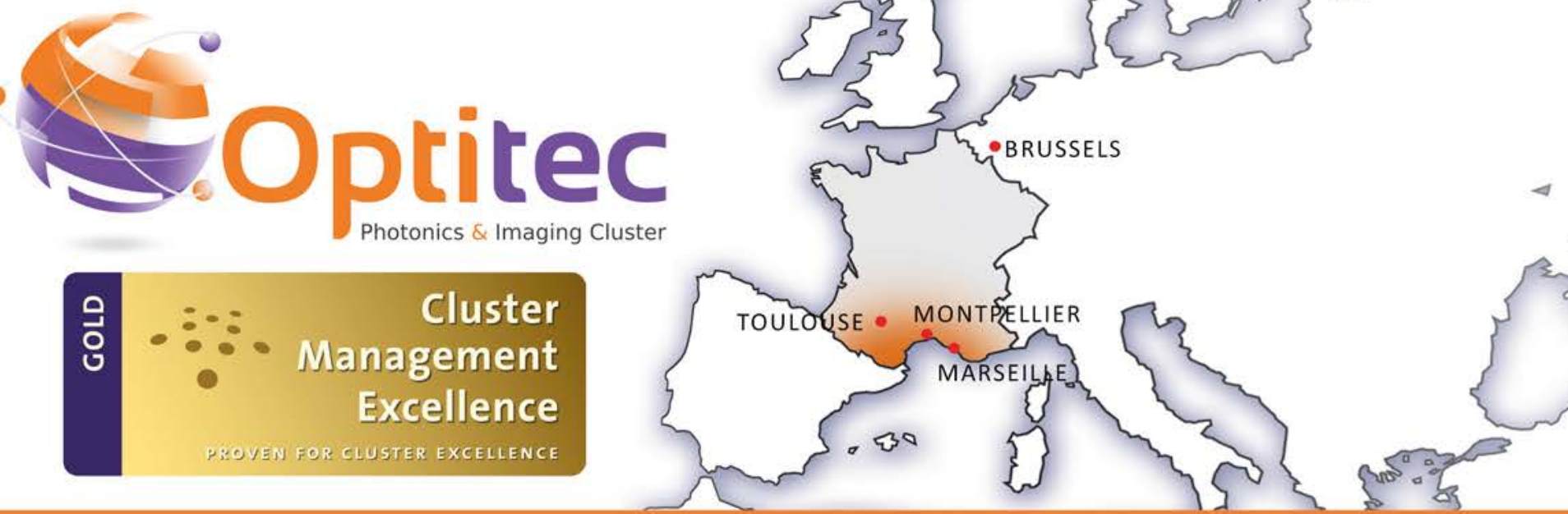

DRIVING THE INNOVATION IN LIGHT

\section{$>$ Leading European Photonics}

\& Imaging Cluster

Headquarters in Marseille, offices in Montpellier and Brussels

$>$ Diversified membership base representing $25 \%$ of French R\&D in photonics

Highly innovative SMEs, leading-edge research centres and universities with world-renowned laboratories

\section{> Horizon2020 project coordinator}

«Empowering Photonics through Regional Innovation Strategies in Europe» (EPRISE)

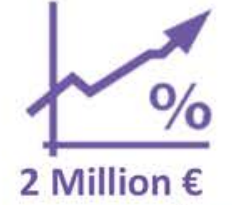

of European funds

secured in the

2014 - 2016 period

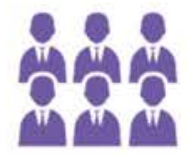

250 members

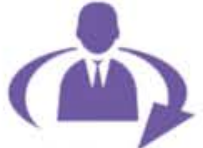

1.6 billion $€$

of annual turnover

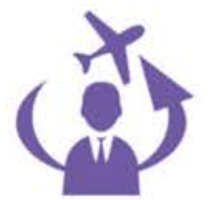

$\mathbf{5 5} \%$ of member's turnover is genereted by export activities

Key application domains: Smart City, Industry of the future, Safety/Defence, Health \& Biomedical
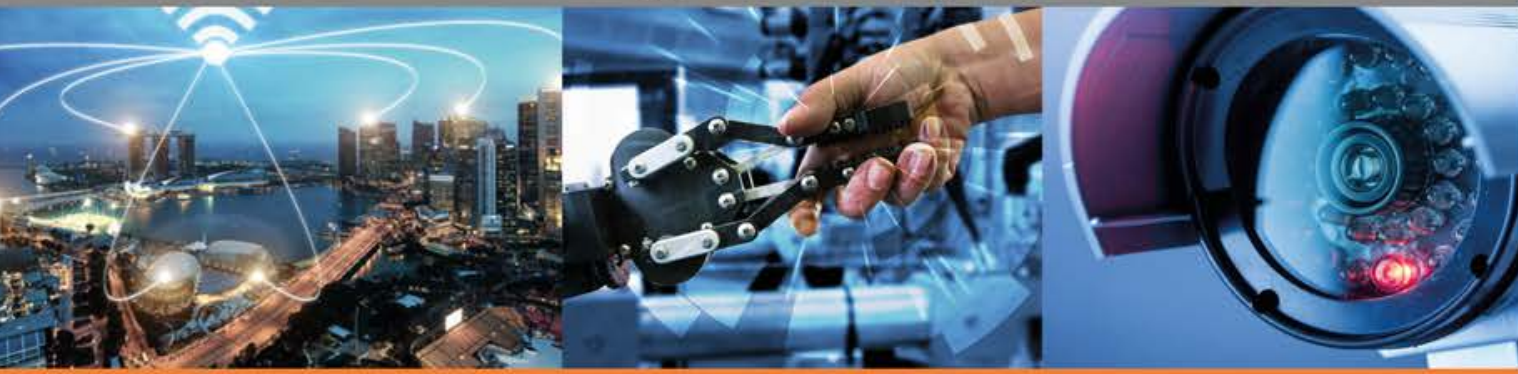

ww w. pole-optitec.com

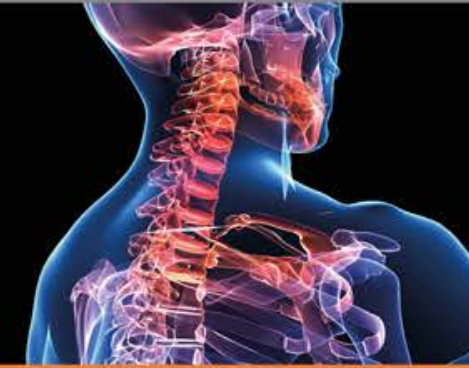

Bin 